\title{
Post Operative Diagnosis of Early Gastric Cancer in a Low Risk Population and the Possibility of Risk Stratified Screening Ghimire $B,{ }^{1}$ Singh $Y P^{1}{ }^{1}$ Timalsina $\mathrm{S}^{2}$
}

${ }^{1}$ Department of Surgery
${ }^{2}$ Department of Biochemistry
Institute of Medicine Tribhuvan University Teaching
Hospital
Kathmandu, Nepal
Corresponding Author
Bikal Ghimire
Department of Surgery
Institute of Medicine Tribhuvan University Teaching
Hospital
Kathmandu, Nepal
Email: bikalghimire@gmail.com

Citation

Ghimire B, Singh YP, Timalsina S. Post Operative Diagnosis of Early Gastric Cancer in a Low Risk Population and the Possibility of Risk Stratified Screening. Kathmandu Univ Med J 2014;45(1):3237.

\section{ABSTRACT}

\section{Background}

Gastric cancer is the second commonest cause of cancer related mortality worldwide. Though its incidence is more in Eastern Asia, it is increasing in the South Asian subcontinent. The diagnosis of early gastric cancer (EGC) confined to the mucosa or submucosa, is an important concern due to a better outcome at this stage where five year survival rates could increase by 90 percent. Though mass screening is done in few countries, it has not been applied in developing countries like Nepal. Preoperative diagnosis of EGC is rare in Nepal. The aim of this study is to analyze the clinicopathological features of postoperative cases of gastric cancer managed in a tertiary care university hospital of Nepal.

\section{Methods}

All patients with histological diagnosis of gastric cancer admitted in the Department of Surgery, Tribhuvan University Teaching Hospital, Kathmandu, Nepal during the three year period (September 2010 to August 2013) were analyzed retrospectively.

\section{Results}

Ninety two patients with endoscopic diagnosis of gastric cancers were admitted during the past three years. The mean age was 60 years ranging from 28 years to 85 years with the male to female ratio of $2.8: 1$. Five patients were younger than 40 years and all were in advanced stage. Thirty five percent of the patients belonged to Janajatis (Hill) community though they comprise only $23 \%$ of the population and about $65 \%$ of them belonged to an area involving $25 \%$ of the country.

Seventy six cases were operated. Out of 92 patients, 4 patients were diagnosed as early gastric cancer postoperatively. All patients with early gastric cancer were above 50 years with CT Scan abdomen revealing focal thickening without lymphadenopathy.

\section{Conclusion}

Over the years, the incidence of gastric cancer is increasing in Nepal. Though $92 \%$ are advance gastric cancers, few have been diagnosed and treated early. A screening program in a country like Nepal with diverse ethnicity and difficult terrain might be helpful if it targets high risk people in high risk areas.

\section{KEY WORDS}

Advanced gastric cancer, early gastric cancer, ethnicity, low risk 


\section{INTRODUCTION}

Gastric cancer is the second commonest cause of cancer related mortality and the fourth commonest malignant disease worldwide. ${ }^{1}$ The risk of gastric cancer varies with higher incidence seen in East Asian countries such as Japan, Korea, China etc. Here the age- standardized incidence rate (ASR) is more than 20 per 100000 . The incidence is low in North America and Europe with ASR less than 10 per 100000 in Australia and New Zealand. ${ }^{2,3}$

Over the years, the incidence of cancer is expected to increase. Without new initiatives for reduction of the high risk factors such as obesity and smoking, the number of cases of cancer in United Kingdom is expected to increase substantially reflecting the growing and aging population. ${ }^{4}$ In Korea, the incidence of gastric cancer was $22 \%$ in Males and $13.7 \%$ in females and the projected increase in cancer incidence is $45.8 \%$ by 2015 with $30 \%$ increase in cancer deaths. ${ }^{5}$ The mortality to incidence ratio is more than 0.8 in more than $70 \%$ of countries suggesting that reversal of late presentation and modification of the treatment strategy are important issues to improve clinical outcomes. ${ }^{1,6}$

Gastric cancer usually presents in advanced stage with five year survival of $10-20 \%$ and early diagnosis confers five year survival of $90 \% .{ }^{7,8}$ The concept of Early gastric cancer (EGC) originated in Japan in 1962. In Eastern Asia, EGC accounts for $50 \%$ of resections for gastric Adenocarcinoma where as in western countries, it accounts for $15-21 \%$ resections. $^{9,10}$

However early diagnosis is only feasible where population based screening is adopted such as in Japan, Korea and Matsu Island in Taiwan. ${ }^{5,11,12}$ Screening also helps to reduce morbidity and mortality from gastric cancer by addressing modifiable environmental risk factors such as diet and $\mathrm{H}$. Pylori infection.

The Age standardized (world) incidence of gastric cancer in Chennai was 12.2 and 6.0 per 100000 population in males and females respectively and it was the highest in India. In New Delhi, it was observed to be at 3.4 per $100000 .^{3}$ In a study done in Kaski district of Nepal, it was found to be 3.3 per $100000 .{ }^{13}$ In Nepal the age standardized death rate from gastric cancer for 2010 is 8.38 and Nepal ranks $71^{\text {st }}$ in the world rank in gastric cancer. ${ }^{14} \mathrm{Nepal}$ is a developing country with limited recourses and the difficult terrain limits accessibility of health care facility by the general population. Ethnicity, culture and tradition determine the environmental factors which contribute to the pathogenesis of gastric cancer. The 2001 census in Nepal identified 103 social groups based on caste, ethnicity, religion, and language making it quite challenging to analyze patterns. To simplify such an analysis, a recent multi-year Gender and Social Exclusion Assessment (GSEA) by the British Department for International Development (DFID) and the World Bank, in collaboration with the National Planning Commission of Nepal, combined the 103 social groups in 10 major categories. (Table 1 )
Table 1. Caste and Ethnic groups in Nepal.

\begin{tabular}{|c|c|c|}
\hline $\begin{array}{l}\text { Share of Popula- } \\
\text { tion }\end{array}$ & Simplified Group & 2001 Census Group \\
\hline \multirow[t]{5}{*}{$\begin{array}{l}\text { Hindu caste } \\
\text { group }(57.5 \%)\end{array}$} & $\begin{array}{l}\text { 1. Brahmans and } \\
\text { Chhetris(Hill) }\end{array}$ & $\begin{array}{l}\text { Brahman, Chhetri, Thakuri, } \\
\text { Sanyasi }\end{array}$ \\
\hline & $\begin{array}{l}\text { 2. Brahmans and } \\
\text { Chhetris (Tarai) }\end{array}$ & $\begin{array}{l}\text { Kayashta, Rajput, Baniya, } \\
\text { Marwadi, Jaine,Nurang, } \\
\text { Bengali }\end{array}$ \\
\hline & $\begin{array}{l}\text { 3. Tarai Middle } \\
\text { Castes }\end{array}$ & $\begin{array}{l}\text { Yadev, Teli, Kalwar, Sudi, } \\
\text { Sonar, Lohar,Koiri, Kurmi, } \\
\text { Kanu, Haluwai, Hajam/ } \\
\text { Thakur, Badhe, Rajbhar, } \\
\text { Kewat, Mallah, Numhar, } \\
\text { Kahar, Lodha, Bing/Banda, } \\
\text { Bhediyar, Mali, Kamar } \\
\text { Dhunia }\end{array}$ \\
\hline & 4. Dalits (Hill) & $\begin{array}{l}\text { Kami, Damai, Sarki, Gaine, } \\
\text { Bad }\end{array}$ \\
\hline & 5. Dalits (Tarai) & $\begin{array}{l}\text { Chamar, Musahar, Tatma, } \\
\text { Bantar, Dhusadadh/Pas- } \\
\text { wan, Khatway, Dom, } \\
\text { Chidimar, Dhobi, Halkhor, } \\
\text { Unidentified Dalit }\end{array}$ \\
\hline \multirow{3}{*}{$\begin{array}{l}\text { Janajatis } \\
(37.2 \%)\end{array}$} & 6. Newar & All Newari Castes \\
\hline & 7. Janajatis (HIII) & $\begin{array}{l}\text { Magar, Tamang, Rai, } \\
\text { Gurung, Limbu, Sherpa, } \\
\text { Bhote, Walung, Buansi, } \\
\text { Hyolmo, Gharti/Bhujel, } \\
\text { Kumal,Sunuwa, Baramu, } \\
\text { Pahari, Adivasi Janajati, } \\
\text { Yakkha, Shantal, Jirel, Da- } \\
\text { rai, Dura, Majhi, Dunuwar, } \\
\text { Thami, Lepcha, Chepang, } \\
\text { Bote, Raji, Hayu, Raute, } \\
\text { Kasunda, }\end{array}$ \\
\hline & 8. Janajatis (Tarai) & $\begin{array}{l}\text { Tharu, Dhanuk, Rajbanshi, } \\
\text { Tajpuriya, Gangai, Dhimal, } \\
\text { Meche, Kisan, Munda, } \\
\text { Santhal/Satar/ Dhungadi/ } \\
\text { Jhangad, Koche, Pattar- } \\
\text { katta/Kusbadiya }\end{array}$ \\
\hline Muslims (4.3\%) & 9. Muslims & Muslims, Churoute \\
\hline Others (1\%) & \multicolumn{2}{|l|}{ 10. Others } \\
\hline
\end{tabular}

Source: World Bank, and Department For International Development (DFID). 2006. Unequal citizens: Gender, caste and ethnic exclusion in Nepal - Summary. Kathmandu: World Bank, Department For International Development. Table 1, page 1

This Tertiary hospital based study was undertaken to identify the incidence of early gastric cancer in the absence of screening and to analyze the demographic profile of patients with gastric cancer to identify high risk population and areas in Nepal.

\section{METHODS}

This was a retrospective study conducted at to the Department of surgery, Tribhuvan University Teaching Hospital from during the three year period (September 2010 to August 2013). Admission records of all the patients with the diagnosis of Gastric cancer were analysed. Patients with the endoscopic biopsy or histopathology report of adenocarcinoma were included in the study. 
According to histopathology, patients were categorized into Early gastric cancer and Advanced gastric cancer based on the AJCC (TNM) staging. ${ }^{15}$

Data regarding demographics, ethnicity, geographical distribution, presenting symptoms, management, days of admission were analyzed. The clinical and radiological findings of patients with early gastric cancer were analyzed.

Ethnicity was divided according to the category published by British Department for International Development (DFID) and the World Bank, in collaboration with the National Planning Commission of Nepal in 2006. ${ }^{16}$ (Table 1)

\section{RESULTS}

Ninety two patients with endoscopic diagnosis of gastric cancers were admitted during the past three years. Of them only two had lymphoma. On Clinical and histopathological examination, most of them were advanced gastric cancers with early gastric cancer observed in only 4 patients. Fifty seven of the patients with gastric Adenocarcinoma were males and the mean age was 60 years ranging from 28 years to 85 years with the male to female ratio of $2.8: 1$. (Fig 1) Five patients were younger than 40 years and all were in

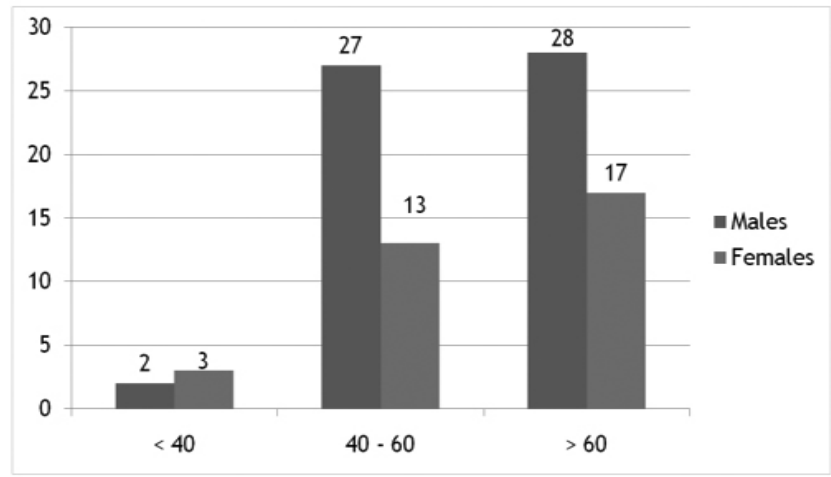

Figure 1. Age distribution of patients with gastric cancer.

advanced stage. The commonest complains at presentation was pain abdomen (87\%), malena was observed in $30 \%$ and $66 \%$ had vomiting. (Fig 2) Consumption of tobacco was observed in $70 \%$ of them where as only $45 \%$ consumed alcohol regularly.

Surgery with curative intent was undertaken in 55 patients,

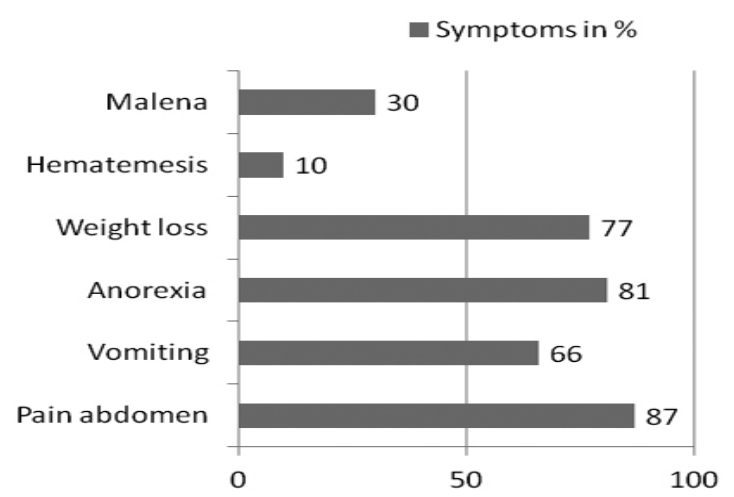

Figure 2. Symptoms at presentation.
21 patients underwent palliative procedures whereas no intervention was done in 14 patients. Subtotal gastrectomy was done for 48 patients and Total gastrectomy for seven. Palliative subtotal gastrectomy was done for 10 patients, Gastrojejunostomy for 8, Feeding jejunostomy for one and lleocolic anastomosis was done for two patients with obstruction of transverse colon. One patient had presented with gastric perforation and was operated in the emergency.

Most of the patients (50\%) belonged to Brahmin and Chhetris (Hill) of the Hindu caste group. This was followed by Janajatis (Hill) $35 \%$ and Newars 11\%, both of whom belonged to the Janajatis and amongst them it was more frequently observed in the Gurung and Sherpa community.

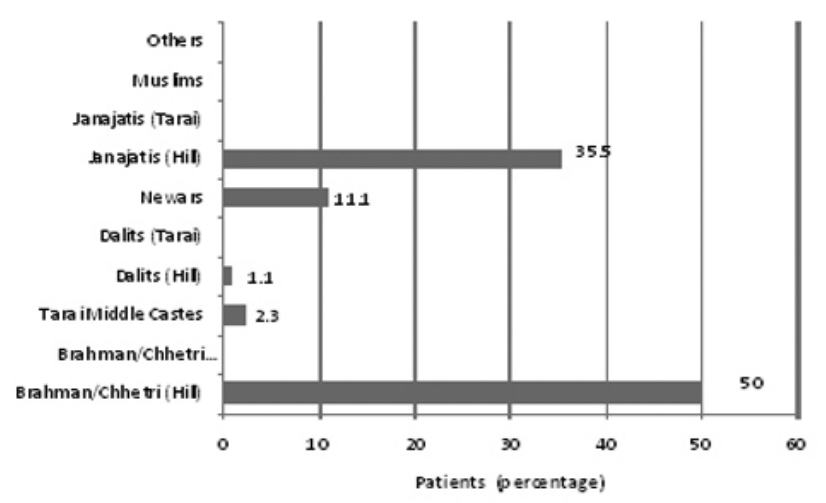

Figure 3. Ethnic distribution of patients with gastric cancer.

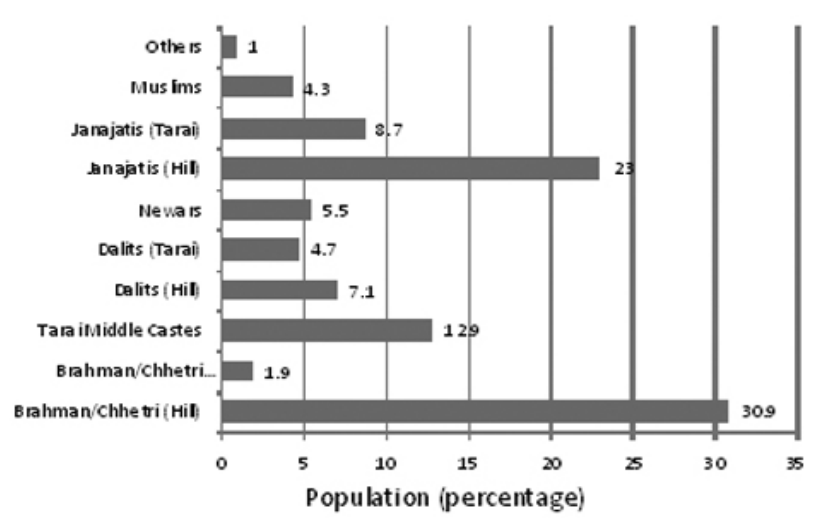

Figure 4. Distribution of various ethnic groups in Nepal (Source: 2001 Census CBS Acharya 2004).

(Fig 3, 4) When we consider the fact that Hindu caste group comprises of $57.5 \%$ and Janajatis $37.2 \%$ of the population, a significant portion of the patients belonged to the Janajatis of the Hills. Overall, $65 \%$ of them belonged to an area involving $25 \%$ of the country. (Fig 5 )

Seventy six cases were operated. On histopathology, out of 92 patients, 4 patients were diagnosed as early gastric cancer postoperatively. (Fig 6 and 7) All patients with early gastric cancer were above 50 years of age and were symptomatic with features upper gastrointestinal bleeding. (Table 2 ). CT Scan abdomen revealed focal thickening without lymphadenopathy in three cases whereas in one CT scan abdomen was normal. (Fig 8) 


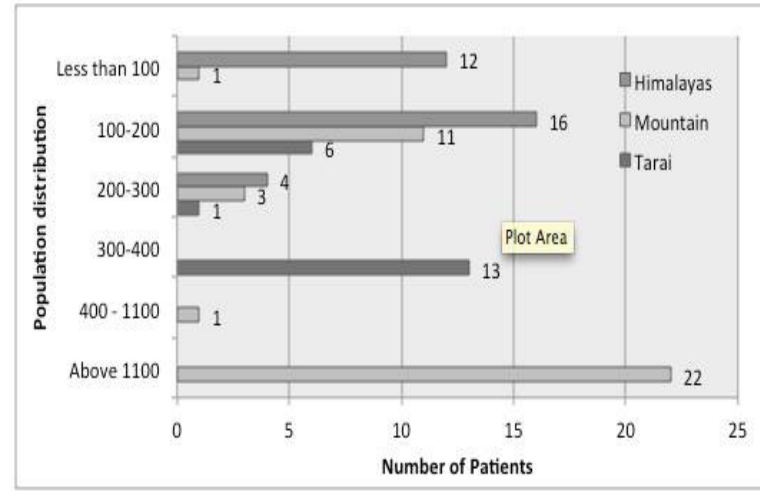

Figure 5. Geographical distribution of patients with gastric cancer.

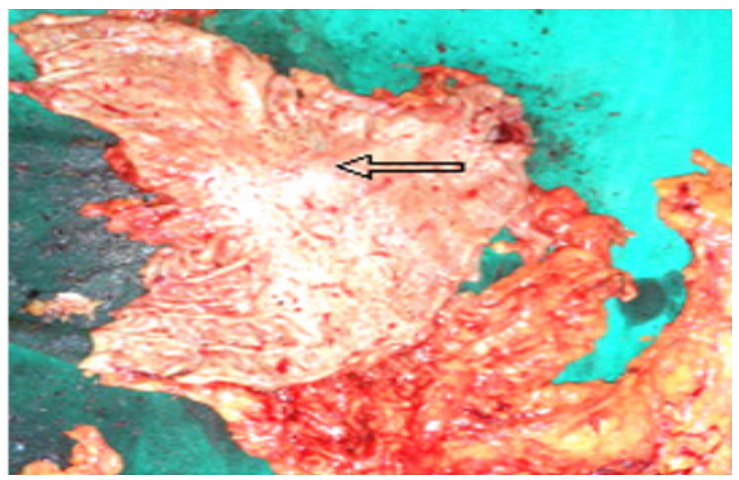

Figure 7. Gross (black arrow) features of Early gastric cancer.

Table 2. Features of patients with Early gastric cancer.

\begin{tabular}{|c|c|c|c|c|}
\hline & Case I & Case II & Case III & Case IV \\
\hline Age & 63 & 52 & 58 & 77 \\
\hline Sex & $\mathrm{F}$ & M & $M$ & $\mathrm{~F}$ \\
\hline $\begin{array}{l}\text { Symptoms } \backslash \\
\text { Sign }\end{array}$ & $\begin{array}{l}\text { Weakness, } \\
\text { anemia, } \\
\text { melena }\end{array}$ & GI Bleeding & $\begin{array}{l}\text { Upper } \\
\text { abdominal } \\
\text { discomfort, } \\
\text { melena }\end{array}$ & $\begin{array}{l}\text { Pain } \\
\text { abdomen, } \\
\text { melena }\end{array}$ \\
\hline UGIE & $\begin{array}{l}\text { Polypoidal } \\
\text { mass in } \\
\text { Lesser } \\
\text { Curvature }\end{array}$ & $\begin{array}{l}\text { Irregular } \\
\text { mass } \\
\text { antrum }\end{array}$ & $\begin{array}{l}\text { Ulcer in } \\
\text { body }\end{array}$ & $\begin{array}{l}\text { Ulceration in } \\
\text { antrum }\end{array}$ \\
\hline CECT & $\begin{array}{l}\text { Focal thick- } \\
\text { ening }\end{array}$ & $\begin{array}{l}\text { Focal } \\
\text { thickening, } \\
\text { no LN }\end{array}$ & $\begin{array}{l}\text { Focal thick- } \\
\text { ening }\end{array}$ & Normal \\
\hline Surgery & $\begin{array}{l}\text { Subtotal } \\
\text { gastrec- } \\
\text { tomy }\end{array}$ & $\begin{array}{l}\text { Subtotal } \\
\text { gastrec- } \\
\text { tomy }\end{array}$ & $\begin{array}{l}\text { Subtotal } \\
\text { gastrectomy }\end{array}$ & $\begin{array}{l}\text { Subtotal gas- } \\
\text { trectomy }\end{array}$ \\
\hline HPE & $\begin{array}{l}3 \mathrm{~cm} \\
\text { polypodal } \\
\text { mass } \\
\text { Well Diff. } \\
\text { adeno ca } \\
\text { T1aNOM0; } \\
0 \backslash 10\end{array}$ & $\begin{array}{l}\text { 2cm ulcer } \\
\text { Well diff. } \\
\text { T1bNOM0; } \\
\text { 0\11 }\end{array}$ & $\begin{array}{l}1 \mathrm{~cm} \text { ulcer } \\
\text { body } \\
\text { Well diff } \\
\text { T1bN1M0 } \\
1 \backslash 34\end{array}$ & $\begin{array}{l}\text { Well diff } \\
\text { T1bNOMO } \\
0 \backslash 10\end{array}$ \\
\hline Follow up & $24 \mathrm{~m}$ & $26 \mathrm{~m}$ & $\begin{array}{l}\text { Adjuvant } \\
\text { chemo (6x } \\
\text { CEF) }\end{array}$ & $6 m$ \\
\hline
\end{tabular}

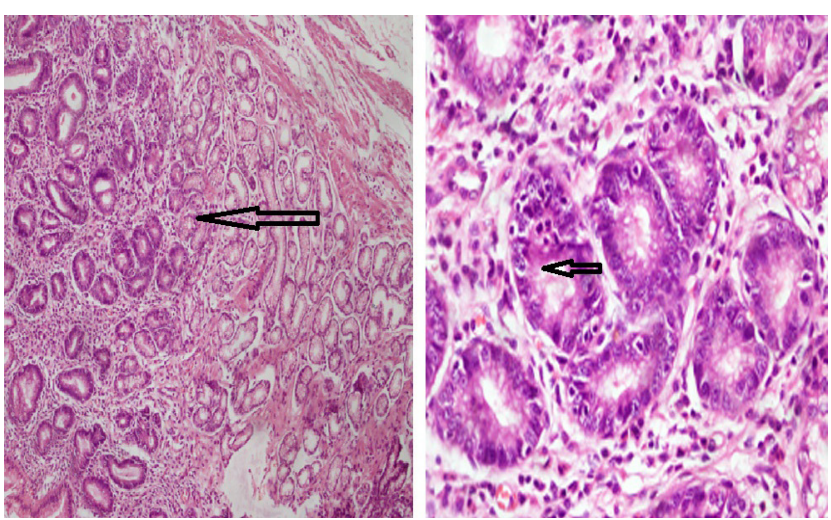

Figure 6. Microscopic features of Early gastric cancer.

Slide a: Gastric mucosa showing interface (Black arrow) between normal mucosal glands (right) and dysplastic glands (left). The intact muscularis mucosa is seen in the upper right corner. (H and E 100X).

Slide b: High power view of dysplastic mucosal glands with mucin depletion high nuclear cytoplasmic ratio and prominient nucleoli (White arrow) in some of the cells. (H and E 400X).

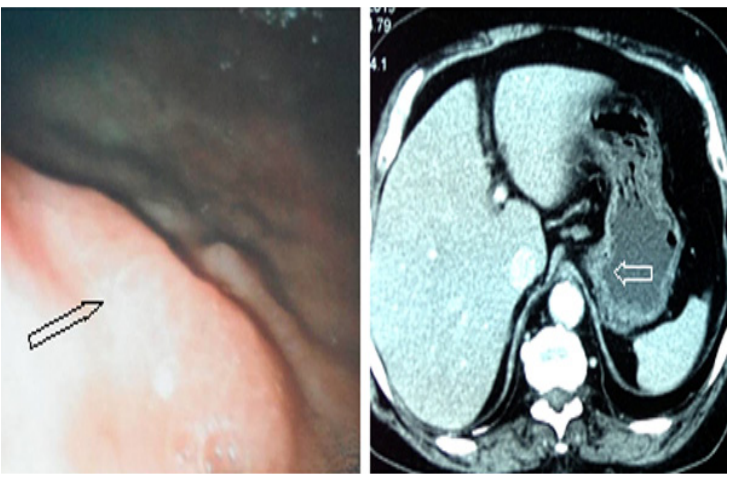

Figure 8. Endoscopic and CT images of stomach in early gastric cancer (Arrow showing the lesion).

\section{DISCUSSION}

Gastric cancer is a common malignancy with very poor prognosis since most are diagnosed in advanced stage. It was found to be the third leading cancer among males $(9 \%)$ and fourth in females $(7.2 \%)$ in a study done in the western regional hospital in Nepal in $2001 .{ }^{17}$ The incidence of gastric cancer is known to increase with age with the peak incidence occurring at $60-80$ years. ${ }^{18}$ Though $50 \%$ in our series were older than 60 years, $44 \%$ were in $40-60$ years group with $5 \%$ in their 3 rd Decade with slight male preponderance (1.7:1). It is similar to that in India where it is common in the 35-55 years in South and $45-55$ years in the North. ${ }^{19}$

Gastric cancer is a multifactorial disease involving apart from $\mathrm{H}$. Pylori infection, diets as well as other risk factors such as ethnicity which were found to be independently associated with non-cardia gastric adenocarcinoma. ${ }^{20}$ There are countries such as India with low gastric cancer age-standardized incidence rate (ASR) (8.9 in Males and 6 in Females) but with high seroprevalence of $\mathrm{H}$ pylori (80 to 90\%) compared to developed countries such as Australia with seroprevalance of $\mathrm{H}$ Pylori of $38 \%$ and ASR of 13.8 to $6.5 \%$ in males and females respectively. ${ }^{21,22}$ However, though strong association of H.Pylori infection was found 
in distal gastric Adenocarcinoma with the relative risk of 5.9; the association was stronger when the blood sample was collected 10 years prior to the diagnosis of cancer. ${ }^{22}$ Smoking and alcohol have been found to increase the risk of gastric cancer and smoking was more commonly observed in our patients.

Demographically, Gastric cancer was found commonly in 61-70 years, and in Gurung community (Janajati- Hill in our category) in a study by Ghosh et al. ${ }^{13,23}$ In our series, though Janajatis comprise $37 \%$ of the population, they accounted for $42 \%$ of cases of gastric carcinomas and around $65 \%$ of the patients were concentrated on 20 districts ( $25 \%$ of the geography). Since these patients belong to the hilly region of the country, it limits their accessibility to health care facilities and devoid them of the benefit of early diagnosis and cure. The practice of traditional medicine is widespread in the developing countries. ${ }^{24}$ About $85 \%$ of Nepalese rural population is dependent on various traditional medical practices. ${ }^{25}$ In Nepal, the traditional healers are initially consulted by the people and they often do not frequent the health care facilities without the permission of the traditional healers. ${ }^{26}$ As their beliefs on witchcraft and reliance on traditional faith healer (TFH) for treatment is quite strong among all the ethnic communities, visit to a health facility becomes inevitable only when problem gets worse or unbearable. ${ }^{27}$

Early gastric cancer (EGC) has a very good prognosis. Over the decades, identification of early gastric cancers in high incidence areas by adapting proper screening endoscopy has helped to improve the outcome in gastric cancer

\section{REFERENCES}

1. Lin Shen Y-SS, Huang-Ming Hu. Management of gastric cancer in Asia: resource-stratified guidelines. Lancet Oncol. 2013;2013(14).

2. Parkin DM, Bray F, Ferlay J, Pisani P. Global cancer statistics, 2002. CA: a cancer journal for clinicians. 2005 Mar-Apr;55(2):74-108.

3. Curado M P E, B Shin HR, Storm H, Ferlay J, Heanue M, Boyle P. Cancer Incidence in Five Continents. IARC Scientific Publications. 2007;IX:160.

4. Mistry M, Parkin DM, Ahmad AS, Sasieni P. Cancer incidence in the United Kingdom: projections to the year 2030. British journal of cancer. 2011 Nov 22;105(11):1795-803.

5. Kim YS, Park HA, Kim BS, Yook JH, Lee MS. Efficacy of screening for gastric cancer in a Korean adult population: a case-control study. Journal of Korean medical science. 2000 Oct;15(5):510-5.

6. Ferlay J SH, Bray F, Forman D, Mathers C, Parkin DM. Cancer incidence and mortality worldwide. IARC Cancer Base GLOBOCANv20. 2008;2010(10).

7. Berrino F, Capocaccia R, Esteve J. Survival of Cancer Patients inEurope: The EUROCARE-2 Study. IARC. Scientific Publications. 1999;151: Lyon, IARC.

8. Kikuchi S, Katada N, Sakuramoto S, Kobayashi N, Shimao H, Watanabe $\mathrm{M}$, et al. Survival after surgical treatment of early gastric cancer: surgical techniques and long-term survival. Langenbeck's archives of surgery / Deutsche Gesellschaft fur Chirurgie. 2004 Apr;389(2):69-74.

9. Shimizu S, Tada M, Kawai K. Early gastric cancer: its surveillance and natural course. Endoscopy. 1995 Jan;27(1):27-31. patients. ${ }^{28}$ In Japan and Korea where there is proper screening program, $50 \%$ and $40 \%$ of gastric cancers treated are early gastric cancers and most of them are younger. ${ }^{29-31}$ Screening the population at risk with endoscopy is the only way to diagnose early gastric cancers. In Nepal as there is no screening programs for gastric cancers the yield of early gastric cancer diagnosed routinely is very low. There is no screening program in Nepal as yet for Gastric cancer. In our institute we only perform endoscopy in symptomatic patients. In our series, of all the patients with gastric cancer, only $3.6 \%$ of patients were diagnosed with EGC.

As this is a hospital based study it may have limitations such as referral and patient bias and hence, may not truly represent the disease in the country. However, it demonstrates a pattern observed in similar studies done in the past. ${ }^{23}$ Gastric cancer involves a combination of genetic, sociocultural and environmental factors. In countries like Nepal with limited resources, diverse ethnicity and difficult terrains, it is of paramount importance to determine the epidemiology of the disease for the judicial utilization of resources.

\section{CONCLUSION}

Though Nepal is a low risk area for gastric cancer, early gastric cancer is rarely diagnosed preoperatively. Gastric cancer is commonly observed in the Janajatis (hill) in Nepal specially in the Gurung and Sherpa community. Selective screening of people with high risk factors in these communities might increase the yield of preoperative diagnosis of early gastric cancers.

10. Everett SM, Axon AT. Early gastric cancer: disease or pseudo-disease? Lancet. 1998 May 2;351(9112):1350-2.

11. Hisamichi S. Screening for gastric cancer. World journal of surgery. 1989 Jan-Feb;13(1):31-7.

12. Liu CY, Wu CY, Lin JT, Lee YC, Yen AM, Chen TH. Multistate and multifactorial progression of gastric cancer: results from communitybased mass screening for gastric cancer. Journal of medical screening. 2006;13 Suppl 1:S2-5.

13. Shrestha UK GA, Alurkar VM. Prevalence of Helicobacter pylori infection, its correlation with gastroduodenal diseases and the incidence of gastric cancer in Nepal. Journal of Advances in Internal Medicine. 2013(02):8.

14. Health Profile: Nepal. [cited 201303 December]. Available from: http://www.worldlifeexpectancy.com/country-health-profile/nepal.

15. Edge SB, Compton CC. The American Joint Committee on Cancer: the 7 th edition of the AJCC cancer staging manual and the future of TNM. Annals of surgical oncology. 2010 Jun;17(6):1471-4.

16. World Bank aDFIDD. Unequal citizens: Gender, caste and ethnic exclusion in Nepal - Summary. World Bank, Department For International Development Kathmandu. 2006.

17. Binu V, Chandrashekhar T, Subba S, Jacob S, Kakria A, Gangadharan P, et al. Cancer pattern in Western Nepal: a hospital based retrospective study. Asian Pacific journal of cancer prevention : APJCP. 2007 AprJun;8(2):183-6. 
18. Nagini S. Carcinoma of the stomach: A review of epidemiology, pathogenesis, molecular genetics and chemoprevention. World journal of gastrointestinal oncology. 2012 Jul 15;4(7):156-69.

19. Jemal A, Bray F, Center MM, Ferlay J, Ward E, Forman D. Global cancer statistics. CA: a cancer journal for clinicians. 2011 MarApr;61(2):69-90.

20. Goh KL, Cheah PL, Md N, Quek KF, Parasakthi N. Ethnicity and H. pylori as risk factors for gastric cancer in Malaysia: A prospective case control study. The American journal of gastroenterology. 2007 Jan;102(1):40-5.

21. Lin SK, Lambert JR, Nicholson L, Lukito W, Wahlqvist M. Prevalence of Helicobacter pylori in a representative Anglo-Celtic population of urban Melbourne. Journal of gastroenterology and hepatology. 1998 May;13(5):505-10.

22. Helicobacter, Cancer Collaborative G. Gastric cancer and Helicobacter pylori: a combined analysis of 12 case control studies nested within prospective cohorts. Gut. 2001 Sep;49(3):347-53.

23. Ghosh A SB, Ghartimagar D, Narasimhan R, Talwar P O. Epidemiologic Analysis of Gastric Carcinoma in the Western Region of Nepal. Nepal Journal of Epidemiology. 2010;1 (1):7.

24. B Raut B KD. Present status of traditional healthcare system in Nepal. IJRAP. 2011;2(3):5.
25. DD D. Population and Society in Nepal. S.C. Joshi (ed) Nepal Himalaya: Geological Perspective, Nainital, India. Himalayan Research Group. 1986:10.

26. B. P. Traditional healers as eye team members in Nepal. Community Eye Health Journal. 1997;10:2.

27. NR. S. Health Seeking Behavior of Rajbanshi Community in Katahari and Baijanathpur of Morang District. Nepal Journal of Nepal Health Research Council. 2004;2(2):5.

28. Sano T, Hollowood A. Early gastric cancer: diagnosis and less invasive treatments. Scandinavian journal of surgery : SJS : official organ for the Finnish Surgical Society and the Scandinavian Surgical Society. 2006;95(4):249-55.

29. Everett SM, Axon AT. Early gastric cancer in Europe. Gut. 1997 Aug;41(2):142-50.

30. Ferlay J SI, Ervik M, Dikshit R, Eser S, Mathers C, Rebelo M et.al. Cancer Incidence and Mortality Worldwide: IARC CancerBase No. 11 [Internet] Lyon. France: International Agency for Research on Cancer. 2013. GLOBOCAN;2012: v1.0.

31. Japanese Gastric Cancer Association Registration C, Maruyama K, Kaminishi M, Hayashi K, Isobe Y, Honda I, et al. Gastric cancer treated in 1991 in Japan: data analysis of nationwide registry. Gastric cancer : official journal of the International Gastric Cancer Association and the Japanese Gastric Cancer Association. 2006;9(2):51-66. 